Article

\title{
A Freshwater Streptomyces, Isolated from Tyume River, Produces a Predominantly Extracellular Glycoprotein Bioflocculant
}

\author{
Uchechukwu U. Nwodo, Mayowa O. Agunbiade, Ezekiel Green, Leonard V. Mabinya and \\ Anthony I. Okoh *
}

Applied and Environmental Microbiology Research Group (AEMREG), Department of Biochemistry and Microbiology, University of Fort Hare, Private Bag X1314, Alice 5700, South Africa;

E-Mails: unwodo@ufh.ac.za (U.U.N.); egreen@ufh.ac.za (E.G.); lmabinya@ufh.ac.za (L.V.M.); mayorlala@gmail.com (M.O.A.)

* Author to whom correspondence should be addressed; E-Mail: aokoh@ufh.ac.za;

Tel.: +27-822-249-760; Fax: +27-866-286-824.

Received: 15 May 2012; in revised form: 18 June 2012 / Accepted: 21 June 2012 /

Published: 13 July 2012

\begin{abstract}
We evaluated bioflocculant production by a freshwater actinobacteria whose 16S rDNA nucleotide sequence was deposited in GenBank as Streptomyces sp. Gansen (accession number HQ537129). Optimum culture conditions for bioflocculant production were an initial medium $\mathrm{pH}$ of 6.8 , incubation temperature of $30^{\circ} \mathrm{C}$, agitation speed of $160 \mathrm{rpm}$ and an inoculum size of $2 \%(\mathrm{v} / \mathrm{v})$ of cell density $1.5 \times 10^{8} \mathrm{cfu} / \mathrm{mL}$. The carbon, nitrogen and cation sources for optimum bioflocculant production were glucose (89\% flocculating activity), ammonium sulfate (76\% flocculating activity) and $\mathrm{MgCl}_{2}$. Bioflocculant pyrolysis showed three step decomposition indicative of three components while chemical analyses showed $78 \%$ carbohydrate and $22 \%$ protein (wt/wt). The mass ratio of neutral sugar, amino sugar and uronic acids was 4.6:2.4:3. FTIR spectrometry indicated the presence of carboxyl, hydroxyl and amino groups, typical for heteropolysaccharide. The bioflocculant showed a lattice structure as seen by SEM imaging. Its high flocculation activity suggests its suitability for industrial applicability.
\end{abstract}

Keywords: bioflocculant; culture conditions; streptomyces; chemical composition; pyrolysis; SEM imaging 


\section{Introduction}

Flocculants have diverse properties which inform their uses in flocculation technology. However, the ability to floc out suspended solutes from solvents indicates their suitability for use in water processing, particularly municipal and wastewater treatment [1-4].

Flocculants are categorized into three groups, namely the inorganic flocculants which includes salts of aluminum (aluminum sulfate and poly-aluminum chloride); the organic synthetic polymeric flocculants (polyacrylamide derivatives and polyethylene imines), and the natural occurring flocculants of microbial origin, termed bioflocculant, which includes chitosan and sodium alginate [5-7]. The inorganic and organic synthetic polymeric flocculants are widely used in industrial processes as they possess high efficiency of flocculation and are inexpensive [6,8]; however associated demerits have been colossal and it includes deleterious health problems such as cancer and neuro-toxicity in the case of polyacrylamide derivatives and polyethylene imines and Alzheimer's disease with respect to salts of aluminum [9-11]. In addition, organic synthetic polymeric flocculants constitute a nuisance to the environmental because they are non-degradable and degradation attempt leaves behind monomeric units which could wash into underground waters [12].

Bioflocculants, on the other hand, are safe, biodegradable and lack secondary pollution from degradation intermediates. The enormous advantages associated with bioflocculants have attracted considerable scientific attention [5,13,14]. However, high production cost and low flocculation efficiency has been a limiting factor for industrial application of microbial-produced flocculants. As a result, there is a continual exploration for microbes with high bioflocculant yield, high flocculation efficiency and minimal production cost.

Though members of the actinobacteria group have been well documented as major sources of secondary metabolites of economic importance (two-thirds occurring as antibiotics), very scanty information exists implicating them in biofloculant production. In this report, we evaluate the bioflocculant production by a freshwater Streptomyces isolated from Tyume river in South Africa. Culture conditions were manipulated to optimize bioflocculant yield and the bioflocculant also characterized for novelty.

\section{Results and Discussion}

\subsection{Actinobacteria Identification}

The polymerase chain reaction (PCR) amplification of the 16S rRNA gene of the gram positive bacteria resulted in a PCR product of the expected size $(1.5 \mathrm{~kb})$. Basic Local Alignment Search Tool (BLAST) analysis of the nucleotide sequence of the 16S rDNA showed the bacteria to have 99\% similarity to that of Streptomyces sp. MEC01 and the nucleotide sequence was deposited in GenBank as Streptomyces sp. Gansen with accession number HQ 537129.

\subsection{The Effect of Starter Culture Density on Bioflocculant Activity}

Inocula cell densities corresponding to $1.0,1.5,3.0$ and $5.0\left(\times 10^{8} \mathrm{cfu} / \mathrm{mL}\right)$ used as $2 \%$ of the fermentation media resulted in flocculation activities of $54 \%, 63 \%, 42 \%$ and $13 \%$ respectively after 
$72 \mathrm{~h}$, while corresponding cell densities measured at $600 \mathrm{~nm}$ optical densities $\left(\mathrm{OD}_{600}\right)$, varied from 0.427 to 3.315 and viable count ranged $27-83 \times 10^{15}$ (cfu/mL) (Figure 1$)$. The viable count method was espoused for the kinetics studies as it showed more accuracy towards measuring cell density at the point of flocculation activity measurement.

Figure 1. Effect of inoculum cell density on bioflocculant production by Streptomyces sp. Gansen (HQ537129).

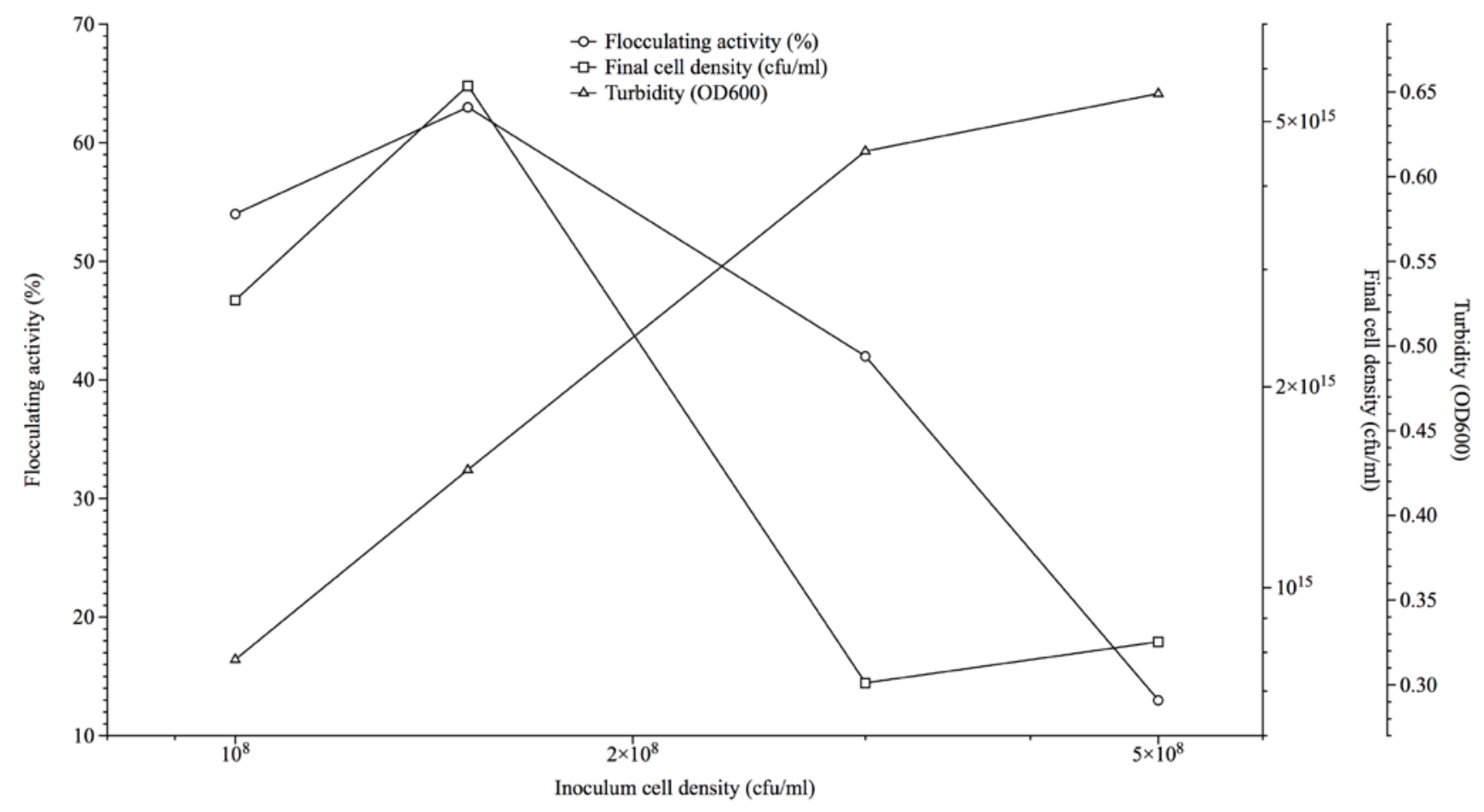

Cost effectiveness in the industrial production of valuable microbial products via fermentation includes optimized inocula cell density to nutrient ratio for synchronous cultures to exhibit maximal potentials. Mullins and NeSmith as well as Gibbons and Westby similarly demonstrated the phenomenon of culture to nutrient ratio optimization in the production of ethanol $[15,16]$.

\subsection{Effect of Culture Conditions on Bioflocculant Production}

The result of the effect of initial medium $\mathrm{pH}$ on bioflocculant production is shown in Figure 2. The highest flocculation activities were initially obtained at $\mathrm{pH}$ range of between 6 and 8 (Figure 2) with flocculation activities of $76 \%$ and $75 \%$ respectively. However, on further evaluation of $\mathrm{pH}$ regimes of between 6 and 8, the highest flocculation activity (82\%) was recorded at $\mathrm{pH} 6.8$ (Figure 2). Also, temperature optimum was observed to be $30{ }^{\circ} \mathrm{C}$ with flocculation activity of about $73.3 \%$ (Figure 2); while agitation speed of $160 \mathrm{rpm}$ was optimum for the bioflocculant production resulting in flocculation activity of about $72 \%$. Subsequent increase in agitation speed (200 to $400 \mathrm{rpm}$ ) resulted in decrease in flocculation activities (Figure 2). The initial fermentation $\mathrm{pH}$ of near neutrality, moderate agitation speed and incubation temperature requirements of the actinobactaria for bioflocculant production appear to be related to its ecological niche being of freshwater milieu where some of the attributes measured might be moderate. Bioflocculant production at neutral $\mathrm{pH}$ was similarly reported 
by Mabinya et al. [17]. Consequently, production costs attributed to physicochemical parameters would be expected to be lower in the event of using Streptomyces sp. Gansen (HQ537129) for bioflocculant production.

Figure 2. The effect of initial fermentation $\mathrm{pH}$, incubation temperature and agitation speed on the production of bioflocculant by Streptomyces sp. Gansen (HQ537129).

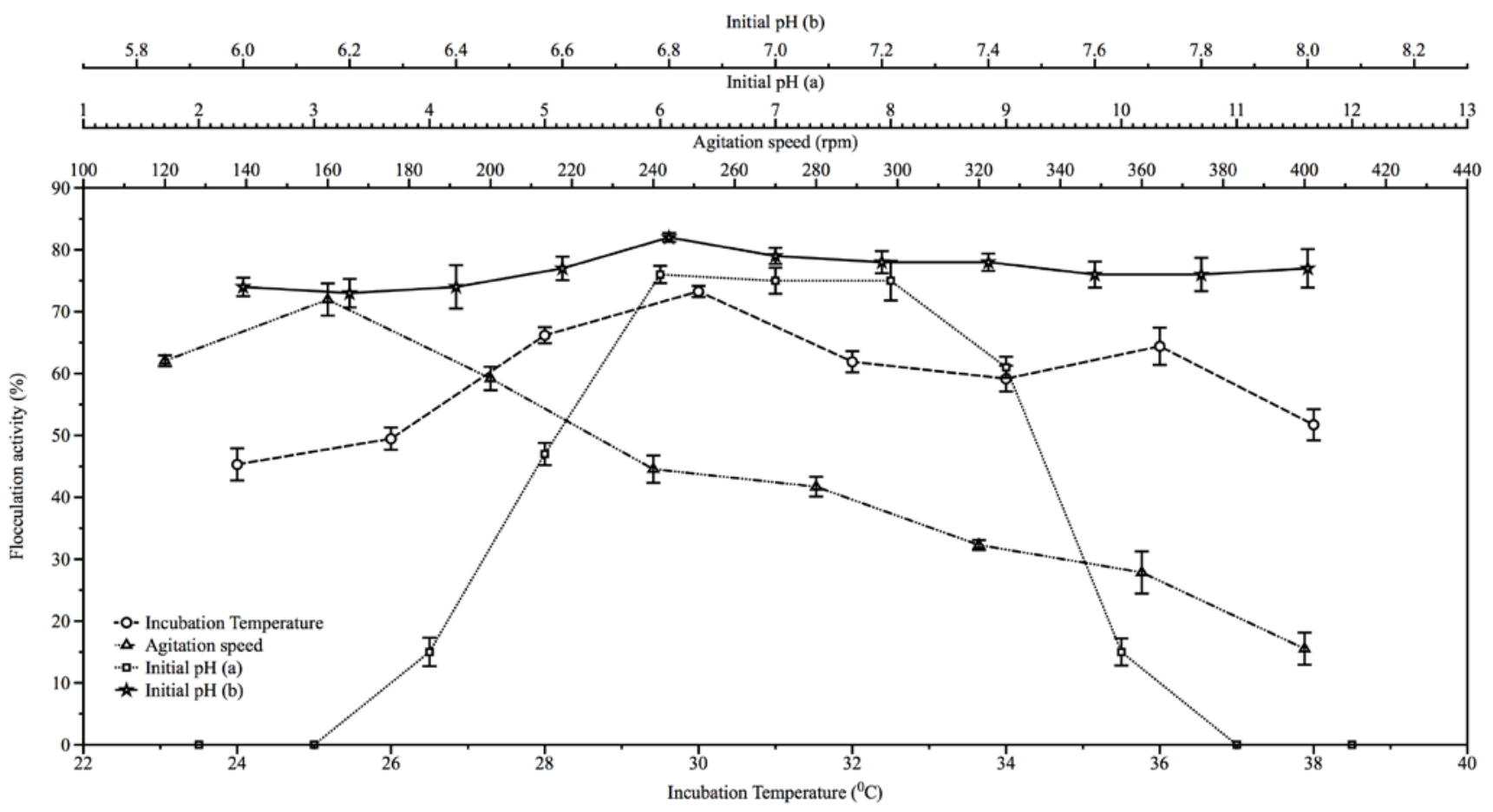

\subsection{Effect of Nutritional Factors on Bioflocculant Production}

Glucose served as best carbon source resulting in optimum flocculation activity of about $89.3 \%$ and bioflocculant yield of $3.37 \mathrm{~g} / \mathrm{L}$. Fructose followed with flocculating activity of about $86.4 \%$ and yield of $3.4 \mathrm{~g} / \mathrm{L}$, while starch showed least flocculation activity (38.9\%) with a yield of $1.52 \mathrm{~g} / \mathrm{L}$ (Table 1). Also, the inorganic nitrogen source (ammonium sulfate) resulted in optimal production of the bioflocculant with flocculation activity of about $76.3 \%$ and bioflocculant yield of $3.26 \mathrm{~g} / \mathrm{L}$; while magnesium chloride was the best cation source with flocculation activity of about $73.2 \%$ with yield of $3.39 \mathrm{~g} / \mathrm{L}$. The choice of cheap nitrogen and cation sources (which are abundant as mineral salts in nature) for bioflocculant production is remarkable from the perspective of the economics of industrial scale production. However, preference of simple sugars, like glucose, fructose and sucrose has been reported to be favorable for bioflocculant production by Corynebacterium glutamicum [13,14]. In the same vein, Gonzales and $\mathrm{Hu}[18]$ reported the stimulation of Flavobacterium sp. by $\mathrm{Ca}^{2+}, \mathrm{Mn}^{2+}$, and $\mathrm{Ba}^{2+}$, in bioflocculant production while Takagi and Kadowaki [19] similarly, reported enhanced cell growth and flocculating activity of Paecilomyces sp. stimulated by $\mathrm{Ca}^{2+}$. 
Table 1. The effects of carbon, nitrogen and cations sources for the production of bioflocculant by Streptomyces sp. Gansen (HQ537129).

\begin{tabular}{|c|c|c|c|c|c|c|c|}
\hline $\begin{array}{l}\text { Carbon } \\
\text { Source }\end{array}$ & Glucose & Lactose & Fructose & Sucrose & Maltose & \multicolumn{2}{|l|}{ Starch } \\
\hline Max. & & & & & & & \\
\hline $\begin{array}{l}\text { Flocculation } \\
\text { activity (\%) }\end{array}$ & 89.26 & 72.54 & 86.41 & 59.33 & 43.0 & 38.9 & \\
\hline $\begin{array}{l}\text { Bioflocculant } \\
\text { yield (g/L) }\end{array}$ & $3.37 \pm 0.22$ & $2.91 \pm 0.40$ & $3.4 \pm 0.17$ & $2.7 \pm 0.13$ & $1.95 \pm 0.37$ & $1.52 \pm 0.31$ & \\
\hline $\begin{array}{l}\text { Nitrogen } \\
\text { Source }\end{array}$ & Urea & $\left(\mathrm{NH}_{4}\right)_{2} \mathrm{SO}_{4}$ & $\left(\mathrm{NH}_{4}\right)_{2} \mathrm{NO}_{3}$ & $\left(\mathrm{NH}_{4}\right)_{2} \mathrm{Cl}_{4}$ & Peptone & & \\
\hline $\begin{array}{l}\text { Max. } \\
\text { Flocculation } \\
\text { activity (\%) }\end{array}$ & 69.18 & 76.27 & 53.45 & 40.18 & 65.63 & & \\
\hline $\begin{array}{l}\text { Bioflocculant } \\
\text { yield (g/L) }\end{array}$ & $1.72 \pm 0.09$ & $3.26 \pm 0.81$ & $2.51 \pm 0.19$ & $1.84 \pm 0.26$ & $2.93 \pm 0.31$ & & \\
\hline $\begin{array}{l}\text { Cation } \\
\text { Source }\end{array}$ & KCl & $\mathrm{NaCl}$ & $\mathrm{MgCl}_{2}$ & $\mathrm{CaSO}_{4} \cdot \mathrm{H}_{2} \mathrm{O}$ & $\mathrm{MnCl} \cdot 4 \mathrm{H}_{2} \mathrm{O}$ & $\mathrm{FeSO}_{4}$ & $\mathrm{FeCl}_{3}$ \\
\hline $\begin{array}{l}\text { Max. } \\
\text { Flocculation } \\
\text { activity (\%) }\end{array}$ & 34.66 & 29.58 & 73.19 & 61.74 & 46.19 & 33.18 & 21.89 \\
\hline $\begin{array}{l}\text { Bioflocculant } \\
\text { yield (g/L) }\end{array}$ & $1.64 \pm 0.33$ & $1.26 \pm 0.52$ & $3.39 \pm 0.05$ & $2.71 \pm 0.38$ & $2.64 \pm 0.71$ & $1.85 \pm 0.51$ & $0.98 \pm 0.31$ \\
\hline
\end{tabular}

\subsection{Kinetics of Bioflocculant Production}

A $2 \%(\mathrm{v} / \mathrm{v})$ starter culture of cell density $1.5 \times 10^{8}(\mathrm{cfu} / \mathrm{mL})$ used for bioflocculant production over a duration of seven (7) days showed growth curve as seen in Figure 3. There was a steep increase in the flocculation activity between $24 \mathrm{~h}$ (7\% activity) to $72 \mathrm{~h}$ (84\% activity) of fermentation and this coincides with the logarithmic growth phase of the actinobacteria as cell density ranged $29 \times 10^{13}$ to $37 \times 10^{15} \mathrm{cfu} / \mathrm{mL}$ respectively. However, maximum flocculation activity (89\%) was achieved at $96 \mathrm{~h}$ of fermentation after which it slowly decreased to 85\% and progressed to $81 \%$ at $104 \mathrm{~h}$ and $128 \mathrm{~h}$ respectively, depicting the stationary and early decline phase of cell growth (Figure 3). At $128 \mathrm{~h}$, there was a steep decline in bacterial cell count and a gradual but steady decline in flocculation activity. The optimal flocculation activity shown at the logarithmic phase of growth is an indication that biosynthetic processes were responsible for production of the bioflocculant in corroboration of the report Lu et al. [20]. 
Figure 3. The growth curve of Streptomyces sp. Gansen (HQ537129) over a period of time with respect to bioflocculant production.

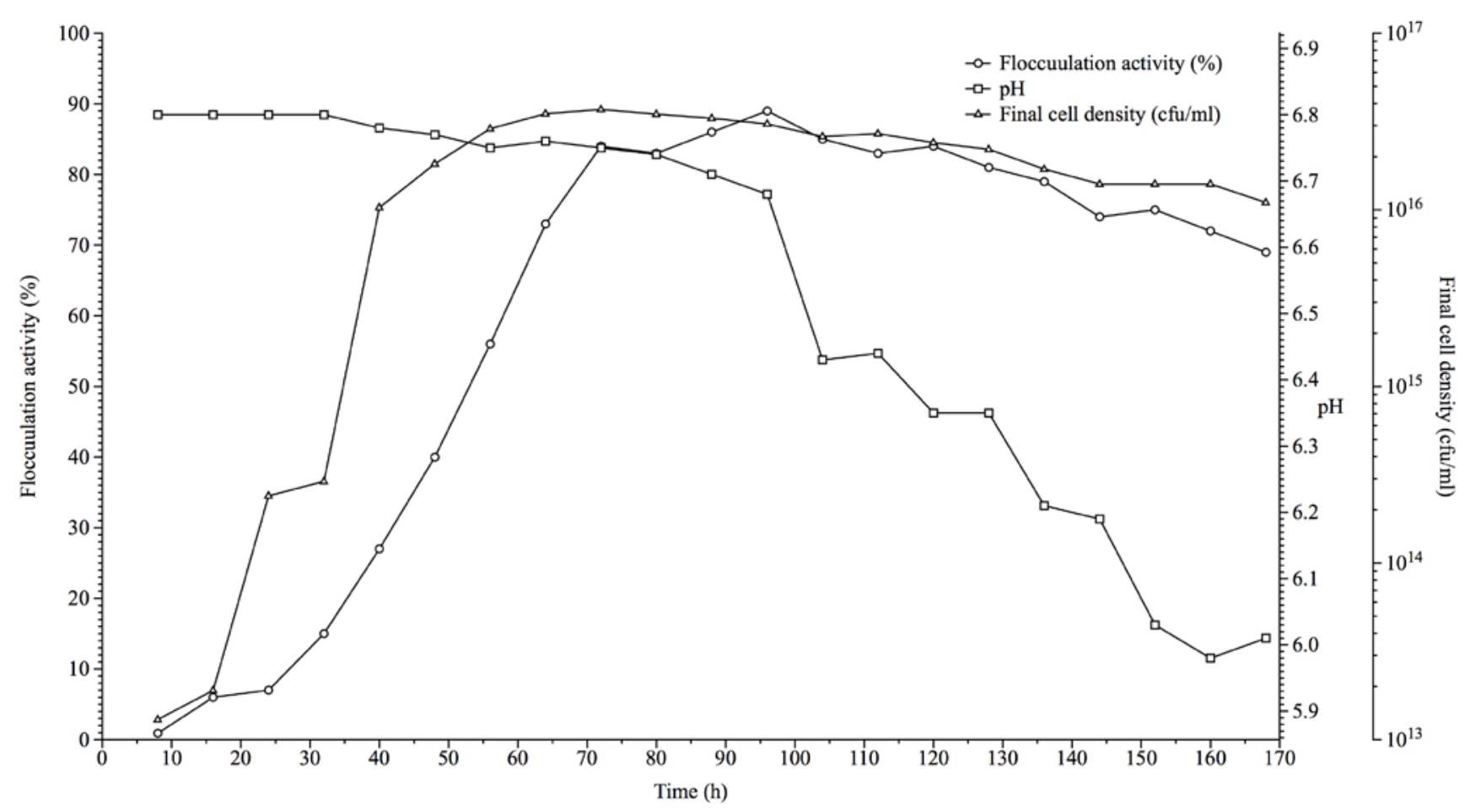

\subsection{Effects of Cations and pH on Flocculation Activity of Purified Bioflocculant}

The effects of monovalent, divalent and trivalent cations on flocculation activity of purified bioflocculant (Table 2), showed that divalent cations aided flocculation better than monovalent and trivalent cations. For example, the following flocculation activities were observed: $87 \%\left(\mathrm{Ca}^{2+}\right)$; $76 \%\left(\mathrm{Mg}^{2+}\right)$; and $62 \%\left(\mathrm{Mn}^{2+}\right)$ respectively, against the partial purified bioflocculant (PPB), and $72 \%\left(\mathrm{Ca}^{2+}\right)$; 57\% $\left(\mathrm{Mg}^{2+}\right)$; and 54\% $\left(\mathrm{Mn}^{2+}\right)$ against the cetylpyridinium chloride (CPC) purified bioflocculant (CPB) respectively. The role of cations in the mediation of flocculation activity by bioflocculants has been similarly documented [21,22]. However, attempt to remove metal ions by dialysis as conducted by Gong et al. [21] was not compare to non dialyzed fraction as has been shown in this study. On the other hand, the monovalent and trivalent cations did not show much variation on their influence on flocculation activity although they showed activity much lower than the divalent cations. However, considering that these cations have different binding capacities, it could be that the divalent metals showed more availability of binding sites and thus more anchorage to the bioflocculants and consequently yielding higher flocculation activity.

Both CPB and PPB achieved optimum flocculation at pH 7 (flocculation activities of 88\% and 77\% respectively) (Table 2). This is not surprising as the effects of $\mathrm{pH}$ and cations are inextricably linked in flocculation process. This is so because at low pH bioflocculants and Kaolin particles absorb hydrogen ions $\left(\mathrm{H}^{+}\right)$and at high $\mathrm{pH}$, hydroxide ions $\left(\mathrm{OH}^{-}\right)$are equally absorbed thereby interfering with the formation of bioflocculant-kaolin complex, thus leaving neutral $\mathrm{pH}$ as optimal for bioflocculation. Similarly, cations have been shown to neutralize negatively charged functional groups of both bioflocculant and suspended particles, thereby increasing the potential for adsorption of suspended particles to the bioflocculant thus enhancing flocculation [23]. Furthermore, the CPC purification of 
bioflocculant did not result in enhance flocculation activity; rather activity declined, thus suggesting that it is not cost effective to process the bioflocculants to CPB state. In addition, it is thought that the decline in activity of CPB is as a result of the use of metal ion surfactant (cetylpyridinium chloride) and subsequent dialysis, in its purification process, which rid the bioflocculant of metal ions to a large degree thus leaving PPB with higher cation content. This may have resulted in the higher flocculation activity observed in the PPB over CPB. In same vein, Cosa et al., [14] and Wang, et al., [24] showed that metal ions aid flocculation process.

Table 2. The effects of cations and medium $\mathrm{pH}$ on the flocculation activity of purified bioflocculant produced by Streptomyces sp. Gansen (HQ537129).

\begin{tabular}{|c|c|c|c|c|c|c|c|c|c|c|c|c|}
\hline \multirow[t]{2}{*}{ Bioflocculant } & \multicolumn{12}{|c|}{ Cation Sources/Flocculation Rate (\%) } \\
\hline & \multicolumn{2}{|c|}{$\mathrm{Na}^{+}$} & $\mathbf{K}^{+}$ & $\mathrm{Mg}^{2+}$ & \multicolumn{2}{|c|}{$\mathrm{Mn}^{2+}$} & \multicolumn{2}{|c|}{$\mathrm{Ca}^{2+}$} & \multicolumn{2}{|c|}{$\mathrm{Fe}^{2+}$} & \multicolumn{2}{|c|}{$\mathrm{Fe}^{3+}$} \\
\hline PPB & \multicolumn{2}{|c|}{$56 \pm 1.4$} & $49 \pm 2.2$ & $76 \pm 0.9$ & \multicolumn{2}{|c|}{$62 \pm 1.6$} & \multicolumn{2}{|c|}{$87 \pm 1.2$} & \multicolumn{2}{|c|}{$47 \pm 1.1$} & \multicolumn{2}{|c|}{$51 \pm 1.9$} \\
\hline \multirow[t]{3}{*}{ CPB } & & 0.8 & $40 \pm 1.7$ & $57 \pm 2.2$ & $54 \pm$ & 0.7 & $72=$ & 1.9 & $42 \pm$ & 0.5 & $46 \pm 1$ & \\
\hline & \multicolumn{12}{|c|}{ pH/Flocculation Rate (\%) } \\
\hline & 2 & 3 & 4 & 5 & 6 & & & 8 & 3 & 9 & 10 & 11 \\
\hline PPB & 0 & $14 \pm 2.5$ & $29 \pm 1.8$ & $38.5 \pm 2.4$ & $49 \pm 2.6$ & 87. & \pm 1.9 & 70.7 & \pm 2.2 & $67 \pm 3.1$ & $64 \pm 2.7$ & $36 \pm 2.3$ \\
\hline CPB & 0 & 0 & $11 \pm 0.8$ & $27 \pm 1.2$ & $39 \pm 0.6$ & 76 & \pm 2.3 & 58.4 & \pm 1.8 & $52 \pm 2.2$ & $45 \pm 1.7$ & $19 \pm 1.5$ \\
\hline
\end{tabular}

\subsection{Compositional Analyses of Purified Bioflocculant}

Chemical analyses of the purified bioflocculant revealed presence of carbohydrates and proteins. However, detailed analyses showed that $100 \mathrm{mg}$ of the purified bioflocculant yielded a total sugar content of $77.9 \mathrm{mg}$ in the $\mathrm{CPB}$ and $76.3 \mathrm{mg}$ in the $\mathrm{PPB}$, while protein content was about $21.9 \mathrm{mg}$ in the CPB and $22.6 \mathrm{mg}$ in the PPB respectively. Further analyses of this carbohydrate component showed the presence of neutral sugars (35.88 mg and $32.94 \mathrm{mg}$ ), amino sugars (18.72 $\mathrm{mg}$ and $19.56 \mathrm{mg}$ ) and uronic acids (23.4 mg and $23 \mathrm{mg}$ ) for CPB and PPB respectively. These carbohydrate components were present in the percentage ratios 4.6:2.4:3 (CPB) and 4.3:2.6:3 (PPB) respectively. Conversely, CPC treatment (purification) did not alter the composition of the bioflocculant with respect to carbohydrates, proteins and other derivatives of $\mathrm{CPB}$ and $\mathrm{PPB}$ and this further confirms that the additional step in purification is unnecessary. The high uronic acid content of the bioflocculant makes it unique and promising for industrial application as bacterial polymers rich in uronic acids have been shown to ameliorate flocculation process $[25,26]$.

\subsection{FTIR Spectroscopy, SEM Micrography and Elemental Composition of Bioflocculant}

Fourier Transform Infrared spectra of the PPB and CPB (Table 3; Figure 4), displayed broad stretching peak at around 3551.57 to $3237.44\left(\mathrm{~cm}^{-1}\right)$ which is characteristic of hydroxyl groups from polymeric and dimeric $\mathrm{OH}$ stretch and a $1401.49 \mathrm{~cm}^{-1}$, typical of phenol or tertiary alcohol $\mathrm{OH}$ bend [27]. Similarly, wave numbers ranging from 2923.77 to $2852.33\left(\mathrm{~cm}^{-1}\right)$ is indicative of a weak $\mathrm{C}-\mathrm{H}$ stretching band while $3378.86 \mathrm{~cm}^{-1}$ is indicative of aliphatic primary amine, $\mathrm{N}-\mathrm{H}$ stretch. An asymmetrical stretching band at 1638.21 and $1549.42\left(\mathrm{~cm}^{-1}\right)$ and a weak symmetrical stretching band near $1401.82 \mathrm{~cm}^{-1}$ indicates the presence of carboxylic groups, carboxylate ions, an aromatic ring 
stretch and C-O and C-O-C from polysaccharides [28]. Likewise, $1107.65 \mathrm{~cm}^{-1}$ is indicative of other sugar derivatives while 622.63 and $478.35 \mathrm{~cm}^{-1}$ shows the presence of disulfides and aryl disulfide (S-S) stretch respectively $[27,28]$.

Table 3. Position and characteristic bond obtained from Fourier Transform Infrared Spectroscopy of bioflocculants from Streptomyces sp. Gansen (HQ537129).

\begin{tabular}{|c|c|c|c|c|c|}
\hline \multirow{2}{*}{ Compound } & \multirow{2}{*}{ Origin } & \multicolumn{3}{|c|}{ Group Frequency Wave Number $\left(\mathrm{cm}^{-1}\right)$} & \multirow{2}{*}{ Assignment/Functional Group } \\
\hline & & Assigned & CPB & PPB & \\
\hline $\begin{array}{l}\text { Hydroxy and } \\
\text { ether } \\
\text { compounds }\end{array}$ & $\mathrm{O}-\mathrm{H}$ & $\begin{array}{c}3570-3200 \\
\text { (broad) }\end{array}$ & $\begin{array}{l}3551.57 \\
3414.22 ; \\
3378.86 ; \\
3237.44\end{array}$ & $\begin{array}{c}3550.86 \\
3413.73\end{array}$ & $\begin{array}{l}\text { Hydroxy group, H-bonded OH } \\
\text { stretch }\end{array}$ \\
\hline \multirow{6}{*}{$\begin{array}{l}\text { Amino } \\
\text { compounds and } \\
\text { Polysaccharides }\end{array}$} & $\mathrm{O}-\mathrm{H}$ & $3400-3200$ & - & - & Normal “polymeric” OH stretch \\
\hline & $\mathrm{O}-\mathrm{H}$ & $3550-3450$ & - & - & Dimeric OH stretch \\
\hline & $\mathrm{O}-\mathrm{H}$ & $1410-1310$ & 1401.49 & 1401.82 & $\begin{array}{l}\text { Phenol or tertiary alcohol, } \mathrm{OH} \\
\text { bend }\end{array}$ \\
\hline & $\mathrm{N}-\mathrm{H}$ & $3400-3380$ & 3378.86 & 3413.73 & $\begin{array}{l}\text { Aliphatic primary amine, } \\
\text { N-H stretch }\end{array}$ \\
\hline & $\mathrm{N}-\mathrm{H}$ & $3510-3460$ & 3551.57 & - & $\begin{array}{l}\text { Aromatic primary amine, } \\
\mathrm{N}-\mathrm{H} \text { stretch }\end{array}$ \\
\hline & $\begin{array}{l}>\mathrm{N}-\mathrm{H} \\
>\mathrm{C}=\mathrm{O} \\
\mathrm{C}-\mathrm{O} \\
\mathrm{C}-\mathrm{H}\end{array}$ & $1650-1550$ & $\begin{array}{l}1638.21 ; \\
1617.85 \\
1549.42\end{array}$ & $\begin{array}{c}1638.37 ; \\
1618.41 ; \\
1548.30\end{array}$ & $\begin{array}{l}\text { Secondary amine, } \mathrm{NH} \text { bend } \\
\text { associated with proteins, } \\
>\mathrm{C}=\mathrm{O} \text { stretch, Ether, } \\
\text { Carboxylic groups, } \\
\mathrm{C}-\mathrm{H} \text { bend from from } \mathrm{CH}_{2} \text {, } \\
\mathrm{C}-\mathrm{O} \text { bend from carboxylate } \\
\text { ions } \mathrm{C}-\mathrm{O} \text {, and } \mathrm{C}-\mathrm{O}-\mathrm{C} \text { from } \\
\text { polysaccharides }\end{array}$ \\
\hline \multirow{2}{*}{ Methyl (-CH3) } & $-\mathrm{CH}$ & $\begin{array}{l}2935-2915 / \\
2865-2845\end{array}$ & $\begin{array}{l}2923.77 ; \\
2852.33\end{array}$ & $\begin{array}{l}2915.12 ; \\
2850.17\end{array}$ & \multirow{2}{*}{$\begin{array}{l}\text { Methylene C-H asym./sym. } \\
\text { stretch } \\
\text { Methyne C-H stretch } \\
\text { (Methyne) } \\
\end{array}$} \\
\hline & $>\mathrm{CH}-$ & $2900-2880$ & 2852.33 & 2850.17 & \\
\hline $\begin{array}{l}\text { Aromatic ring } \\
\text { (aryl) }\end{array}$ & $\mathrm{C}=\mathrm{C}-\mathrm{C}$ & $1510-1450$ & 1549.42 & 1548.30 & Aromatic ring stretch \\
\hline \multirow{2}{*}{$\begin{array}{c}\text { Thiols and } \\
\text { thio-substituted } \\
\text { compounds }\end{array}$} & S-S & $620-600$ & 622.63 & 621.84 & Disulfides (S-S stretch) \\
\hline & S-S & 500-430 & 478.35 & 478.35 & Aryl disulfides (S-S stretch) \\
\hline
\end{tabular}

CPB = wave number $\left(\mathrm{cm}^{-1}\right)$ obtained for CPC purified bioflocculant; PPB = wave number $\left(\mathrm{cm}^{-1}\right)$ obtained for partial purified bioflocculant. 
Figure 4. FTIR spectra of purified bioflocculant produced by Streptomyces sp. (Gansen) HQ537129 (a) partial purified bioflocculant (PPB) and (b) cetylpyridinium chloride (CPC) purified bioflocculant (CPB).

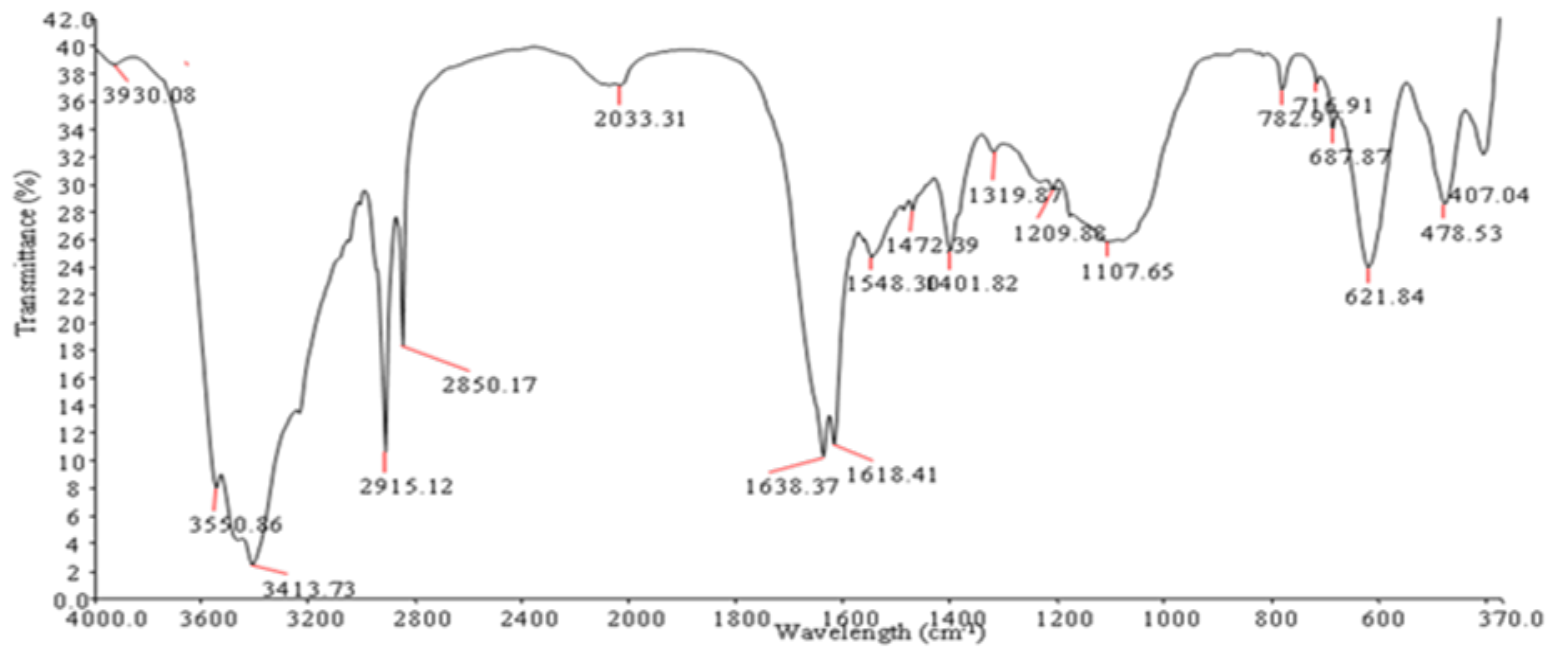

(a)

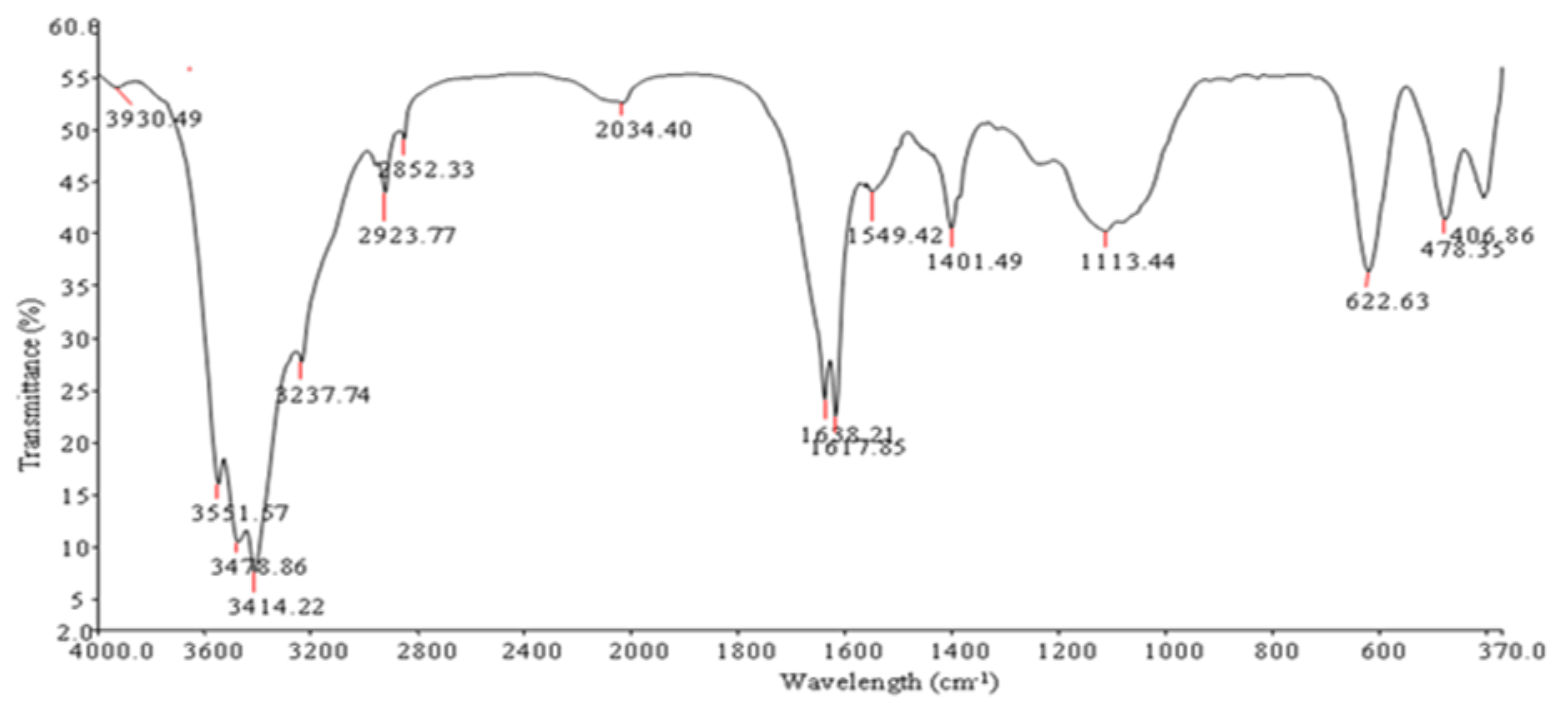

(b)

Morphological elucidation of PPB and CPB via scanning electron micrograph shows a mesh like filamentous structure for CPB (Figure 5a), in marked difference from the PPB structure. Unlike the metal surfactant treated bioflocculants ( $\mathrm{CPB}$ ), PPB appeared to have a clump like structure with similarity to CPB only in the compact nature of the mesh (Figure 5b). Elemental analysis of PPB and CPB yields closely similar spectra with exception only in extent of peaks. These peaks are an indication of the quantity of the elements present. Quantification of these spectra (Table 4), showed PPB and CPB to have high ratios of Carbon (C), Nitrogen $(\mathrm{N})$ and Oxygen (O). Sulfur and Phosphorus was detected in varying amounts. Furthermore, the variety of metal ions detected in PPB was more compared to CPB and this may have accounted for difference in structure as metal ions will cause PPB to be bound compactly. The presences of other elements as indicated by elemental analysis may be an indication that the bioflocculant is organo-metallic, or perhaps the metals could have originated from 
the fermentation medium. The FTIR spectrometry and elemental analysis gives better details of the presence of carbohydrates, proteins and possibly other components not assayed for as more functional groups were detected than have been accounted for.

Figure 5. SEM Micrograph of purified bioflocculant from Streptomyces sp. Gansen (HQ537129). (a) CPB and (b) PPB.

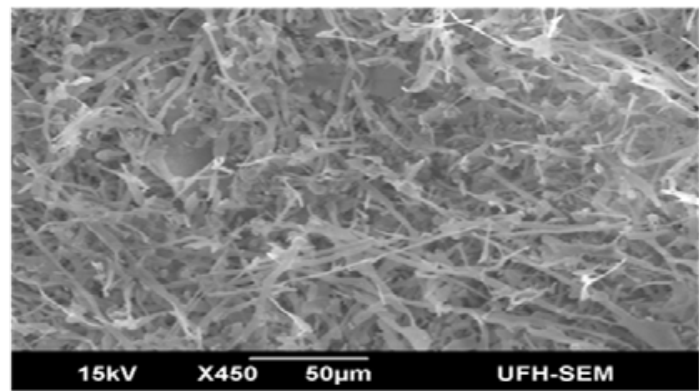

(a)

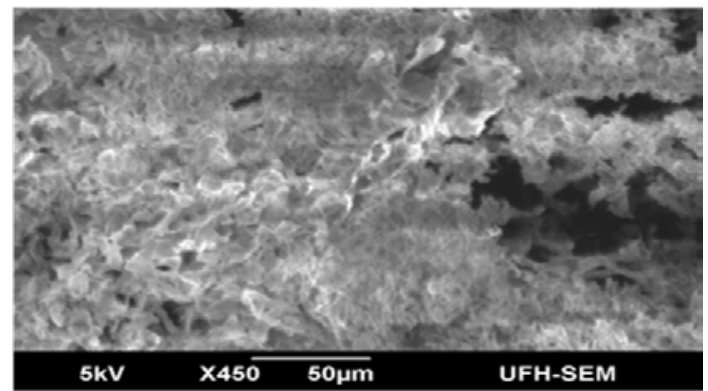

(b)

Table 4. Quantification of the elemental composition of bioflocculant produced by Streptomyces sp. Gansen (HQ537129).

\begin{tabular}{|c|c|c|c|c|c|c|}
\hline \multicolumn{7}{|c|}{ Partial Purified Bioflocculant } \\
\hline $\begin{array}{c}\text { Element } \\
\text { Line }\end{array}$ & $\begin{array}{c}\text { Element } \\
\text { Wt. \% }\end{array}$ & $\begin{array}{l}\text { Wt.\% } \\
\text { Error }\end{array}$ & Atom \% & $\begin{array}{c}\text { Atom \% } \\
\text { Error }\end{array}$ & $\begin{array}{c}\text { Compound } \\
\text { Formula }\end{array}$ & $\begin{array}{c}\text { Compound } \\
\text { Wt. \% }\end{array}$ \\
\hline C K & 24.82 & $+/-1.05$ & 48.22 & $+/-2.04$ & $\mathrm{C}$ & 24.82 \\
\hline N K & 7.14 & $+/-1.36$ & 11.89 & $+/-2.27$ & $\mathrm{~N}$ & 7.14 \\
\hline $\mathrm{OK}$ & 20.61 & $+/-0.50$ & 30.06 & $+/-0.72$ & $\mathrm{O}$ & 20.61 \\
\hline Na K & 0.25 & $+/-0.06$ & 0.26 & $+/-0.06$ & $\mathrm{Na}$ & 0.25 \\
\hline $\operatorname{Mg~K}$ & 0.63 & $+/-0.04$ & 0.60 & $+/-0.04$ & $\mathrm{Mg}$ & 0.63 \\
\hline $\mathrm{Al} \mathrm{K}$ & 0.14 & $+/-0.04$ & 0.12 & $+/-0.03$ & $\mathrm{Al}$ & 0.14 \\
\hline P K & 2.84 & $+/-0.12$ & 2.14 & $+/-0.09$ & $\mathrm{P}$ & 2.84 \\
\hline S K & 1.06 & $+/-0.10$ & 0.77 & $+/-0.07$ & S & 1.06 \\
\hline K K & 0.57 & $+/-0.05$ & 0.34 & $+/-0.03$ & $\mathrm{~K}$ & 0.57 \\
\hline Ca K & 0.32 & $+/-0.05$ & 0.19 & $+/-0.03$ & $\mathrm{Ca}$ & 0.32 \\
\hline $\mathrm{Cu} \mathrm{K}$ & 1.92 & $+/-0.30$ & 0.71 & $+/-0.11$ & $\mathrm{Cu}$ & 1.92 \\
\hline In $\mathrm{L}$ & 0.00 & $+/-0.00$ & 0.00 & --- & In & 0.00 \\
\hline $\mathrm{Au} \mathrm{L}$ & 39.69 & $+/-3.40$ & 4.70 & $+/-0.40$ & $\mathrm{Au}$ & 39.69 \\
\hline \multicolumn{7}{|c|}{ CPC Purified Bioflocculant } \\
\hline C K & 38.09 & $+/-0.74$ & 64.23 & $+/-1.24$ & $\mathrm{C}$ & 38.09 \\
\hline N K & 3.38 & $+/-1.28$ & 1.86 & $+/-2.29$ & $\mathrm{~N}$ & 3.38 \\
\hline $\mathrm{OK}$ & 15.95 & $+/-0.72$ & 20.19 & $+/-0.91$ & $\mathrm{O}$ & 15.95 \\
\hline Na K & 3.21 & $+/-0.14$ & 2.83 & $+/-0.13$ & $\mathrm{Na}$ & 3.21 \\
\hline $\mathrm{Al} \mathrm{K}$ & 0.40 & $+/-0.05$ & 0.30 & $+/-0.04$ & $\mathrm{Al}$ & 0.40 \\
\hline P K & 1.24 & $+/-0.11$ & 0.81 & $+/-0.07$ & $\mathrm{P}$ & 1.24 \\
\hline S K & 0.62 & $+/-0.15$ & 0.39 & $+/-0.09$ & S & 0.62 \\
\hline $\mathrm{Cl} \mathrm{K}$ & 8.10 & $+/-0.22$ & 5.77 & $+/-0.13$ & $\mathrm{Cl}$ & 8.10 \\
\hline K K & 0.33 & $+/-0.07$ & 0.17 & $+/-0.04$ & K & 0.33 \\
\hline $\mathrm{Cu} \mathrm{K}$ & 2.30 & $+/-0.45$ & 0.73 & $+/-0.14$ & $\mathrm{Cu}$ & 2.30 \\
\hline $\mathrm{Au} \mathrm{L}$ & 26.47 & $+/-4.76$ & 2.72 & $+/-0.49$ & $\mathrm{Au}$ & 26.47 \\
\hline
\end{tabular}




\subsection{Thermal Analyses of Purified Bioflocculant}

Thermal properties of PPB and CPB as studied by TGA, in the temperature range of 20 to $900{ }^{\circ} \mathrm{C}$ under nitrogen atmosphere, showed changes in content with decomposition. The mass loss of components is shown in the thermo-gravimetric plots (Figure 6). CPB and PPB started to decompose above $24{ }^{\circ} \mathrm{C}$ and $60{ }^{\circ} \mathrm{C}$ respectively. The thermo-gram for CPB and PPB exhibited three distinct decomposition steps which are similar to the pattern of decomposition for organic compounds documented by Niu et al. [29]. These steps were at $24{ }^{\circ} \mathrm{C}, 215{ }^{\circ} \mathrm{C}$ and $432{ }^{\circ} \mathrm{C}$ for $\mathrm{CPB}$ and $60{ }^{\circ} \mathrm{C}$, $259^{\circ} \mathrm{C}$ and $493{ }^{\circ} \mathrm{C}$ for PPB respectively. The first decomposition step of CPB stretched from $24^{\circ} \mathrm{C}$ to $214{ }^{\circ} \mathrm{C}$, while PPB stretched from $60{ }^{\circ} \mathrm{C}$ to $267{ }^{\circ} \mathrm{C}$ with corresponding weight loss of $0.4 \mathrm{mg}$ and $0.5 \mathrm{mg}$ respectively. Similarly, the second decomposition steps stretched up to $534{ }^{\circ} \mathrm{C}$ (CPB) and $567{ }^{\circ} \mathrm{C}$ (PPB) with weight loss of $1.9 \mathrm{mg}$ and $1.8 \mathrm{mg}$ respectively. This pyrolysis study suggests that the bioflocculant was basically composed of three compounds. This was validated via melting/decomposition temperatures which did not show a sharp point, but rather stretched over a range (results not shown), suggesting that the bioflocculant is composed of more than a single compound.

Figure 6. Pyrolysis curve of CBP and PPB through thermogravimetric analysis.

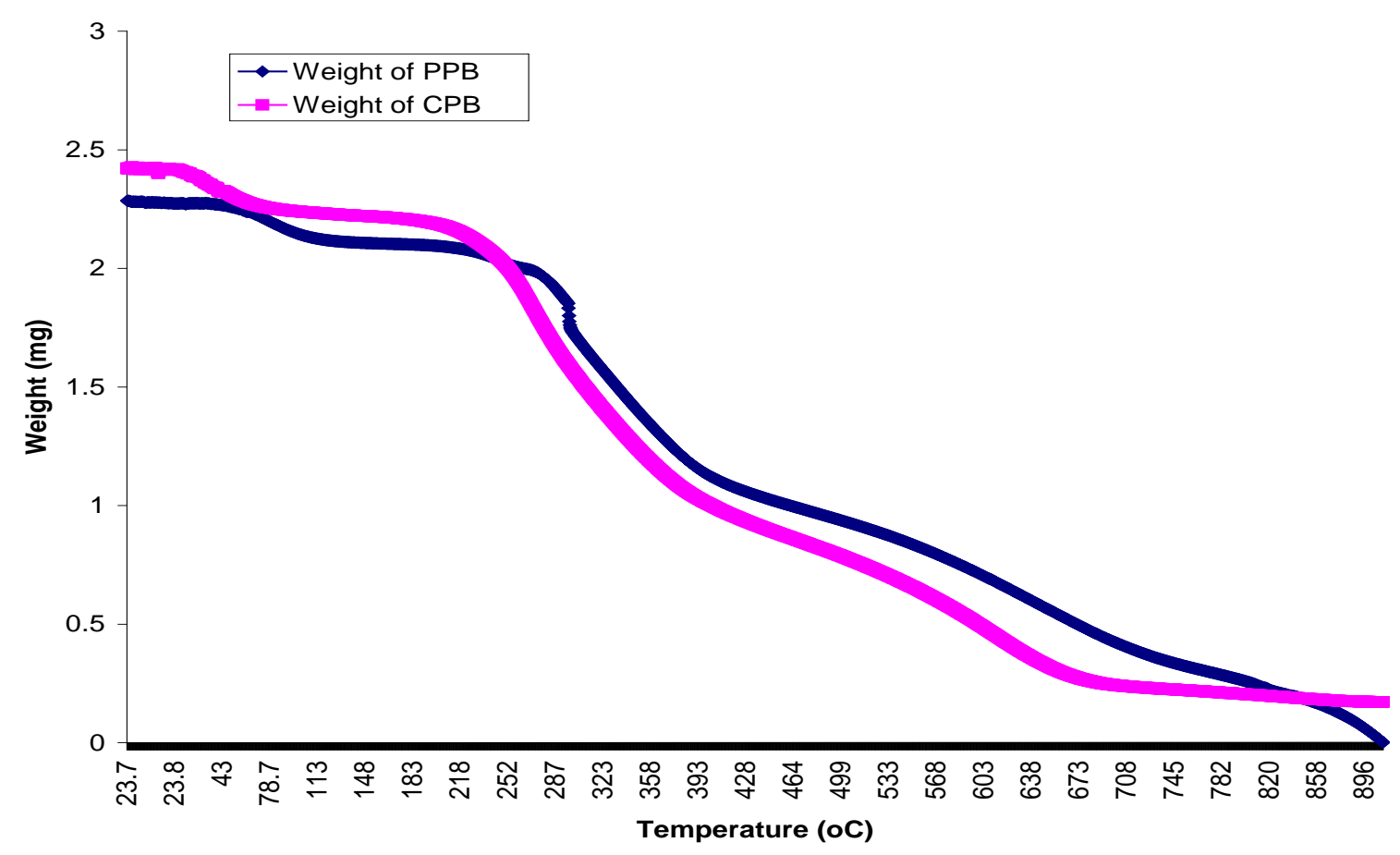

\section{Experimental Section}

\subsection{Activation of Test Bacteria}

An actinobacteria was previously isolated from water sample collected from Tyume river, Eastern Cape, South Africa, as part of the collections of the Applied and Environmental Microbiology Research Group (AEMREG), University of Fort Hare, South Africa. The bacteria was activated by inoculation into a sterile $5 \mathrm{~mL}$ broth composed of $3 \mathrm{~g}$ beef extract, $10 \mathrm{~g}$ tryptone and $5 \mathrm{~g} \mathrm{NaCl}$ (per liter), and incubated aerobically overnight at $28^{\circ} \mathrm{C}$ and $120 \mathrm{rpm}$. 


\subsection{Screening for Bioflocculant Production}

The fermentation broth used in this study is the Basal salt media (BSM) composed as follows (g/L): glucose, 10; tryptone, $1 ; \mathrm{K}_{2} \mathrm{HPO}_{4}, 5 ; \mathrm{KH}_{2} \mathrm{PO}_{4}, 2$ and $\mathrm{MgSO}_{4} \cdot 7 \mathrm{H}_{2} \mathrm{O}, 0.3$ [30]. A set of $500 \mathrm{~mL}$ flasks containing $200 \mathrm{~mL}$ fermentation medium (BSM) were aseptically inoculated with activated culture, by transferring $2 \%(4 \mathrm{~mL})$ of the culture [15,16], adjusted to cell density of about $1.5 \times 10^{8} \mathrm{cfu} / \mathrm{mL}$ [31] and incubating at a temperature of $28{ }^{\circ} \mathrm{C}$ for $72 \mathrm{~h}$ at140 rpm. After the incubation period, the fermentation broth was centrifuged (3000 rpm, $30 \mathrm{~min}, 15^{\circ} \mathrm{C}$ ) to separate the bacterial cells and the cell-free supernatant was assessed for flocculation activity.

\subsection{Effect of Inoculum Size on Bioflocculant Production}

Four flasks containing $200 \mathrm{~mL}$ fermentation medium were aseptically inoculated with $4 \mathrm{~mL}$ of the activated culture adjusted to cell densities of $1.0,1.5,3.0$ and $5.0\left(\times 10^{8} \mathrm{cfu} / \mathrm{mL}\right)$ respectively. These cultures were incubated at a temperature of $28{ }^{\circ} \mathrm{C}$ for $72 \mathrm{~h}$ at $140 \mathrm{rpm}$. After the incubation period, a portion of the fermentation broth was centrifuged (3000 rpm, $30 \mathrm{~min}, 15^{\circ} \mathrm{C}$ ) and the supernatant was assessed for flocculation activity. Other portion was used to determine bacterial load via viable cell count (cfu/mL) and turbidimetrically $\left(\mathrm{OD}_{600}\right)$.

\subsection{Measurement of Flocculation Activity}

Flocculation activity was measured following the method of Zhang et al. [30] with slight modifications. Briefly, $0.3 \mathrm{~mL}$ of $1 \% \mathrm{CaCl}_{2}$ and $0.2 \mathrm{~mL}$ of bioflocculant were added into $10 \mathrm{~mL}$ of Kaolin suspension $(4.0 \mathrm{~g} / \mathrm{L})$ in a test tube. The mixture was vortexed using a vortex mixer (VM-1000, Digisystem) for $30 \mathrm{~s}$ and kept still for $5 \mathrm{~min}$ afterwards, $2 \mathrm{~mL}$ of the upper layer was carefully withdrawn and its optical density (OD) read spectrophotometrically (Helios Epsilon, USA) at $550 \mathrm{~nm}$ wavelength. A control experiment was conducted by repeating same process however; the bioflocculant broth was replaced with sterile (un-inoculated) fermentation medium. All assays were conducted in triplicates and the flocculation activity calculated using the following equations:

$$
\text { Flocculating activity }=\{(\mathrm{A}-\mathrm{B}) / \mathrm{A}\} \times 100 \%
$$

$\mathrm{A}$ and $\mathrm{B}$ are $\mathrm{OD}_{550}$ (optical density; $550 \mathrm{~nm}$ ) of the control and sample, respectively.

\subsection{Effect of Culture Conditions}

Eleven flasks of $500 \mathrm{~mL}$ capacity, containing $200 \mathrm{~mL}$ fermentation medium were adjusted with $0.1 \mathrm{M} \mathrm{NaOH}$ and $0.1 \mathrm{M} \mathrm{HCl}$ to $\mathrm{pH}$ values corresponding from 2 to 12 . Each flask was aseptically inoculated with activated culture $\left(1.5 \times 10^{8} \mathrm{cfu} / \mathrm{mL}\right)$ amounting to $2 \%$ of fermentation medium. These cultures were incubated at a temperature of $28{ }^{\circ} \mathrm{C}$ for $72 \mathrm{~h}$ at $140 \mathrm{rpm}$. After incubation, the fermentation broth was centrifuged (3000 rpm, $30 \mathrm{~min}, 15{ }^{\circ} \mathrm{C}$ ) and the supernatant assessed for flocculation activity. The initial $\mathrm{pH}$ of the medium with optimum yield was repeated, but in incremental factor of 0.2 up to the next absolute value. After $72 \mathrm{~h}$ of incubation at $140 \mathrm{rpm}$ the fermentation broth was centrifuged (3000 rpm, $30 \mathrm{~min}, 15^{\circ} \mathrm{C}$ ) and the supernatant assessed for flocculation activity. Similarly, the effects of incubation temperatures and agitation speed were 
assessed by varying incubation temperature by a unit of 2 from 24 to $38{ }^{\circ} \mathrm{C}$ while agitation speed varied by a unit of 40 from 120 to $400 \mathrm{rpm}$.

\subsection{Effects of Carbon, Nitrogen and Cation sources on Bioflocculant Production}

The BSM described in section 3.2 was used to assess the effects of carbon, nitrogen and cations on bioflocculant production, however, the sole carbon (glucose, fructose, sucrose, lactose, maltose and starch) and nitrogen (urea, ammonium sulfate, ammonium nitrate, ammonium chloride and peptone) sources were varied. Also, sole cation sources include monovalent salts ( $\mathrm{KCl}$ and $\mathrm{NaCl}$ ), divalent salt $\left(\mathrm{MgSO}_{4}, \mathrm{CaSO}_{4} \cdot \mathrm{H}_{2} \mathrm{O}, \mathrm{MnCl} \cdot 4 \mathrm{H}_{2} \mathrm{O}\right.$, and $\left.\mathrm{FeSO}_{4}\right)$ and trivalent salt $\left(\mathrm{FeCl}_{3}\right)$. The fermentation conditions and assessment of culture supernatant for flocculation activity were same as in section 3.2.

\subsection{Kinetics of Bioflocculant Production}

A $200 \mathrm{~mL}$ fermentation medium inoculated with activated culture $\left(1.5 \times 10^{8} \mathrm{cfu} / \mathrm{mL}\right)$ amounting to $2 \%$ of the fermentation medium was incubated at $30{ }^{\circ} \mathrm{C}$ and $160 \mathrm{rpm}$ and $\mathrm{pH}$ of 6.8 in a shaker incubator (based on optimum conditions determined previously). Bioflocculant production kinetics was monitored by withdrawing $5 \mathrm{~mL}$ of the fermentation broth; $4 \mathrm{~mL}$ was used for $\mathrm{pH}$ determination and assessment of flocculation activity, while the remaining $1 \mathrm{~mL}$ used to determine bacterial cell growth via viable cell count (cfu/mL). This process was conducted at $8 \mathrm{~h}$ interval for a period of 7 days.

\subsection{Purification of Bioflocculant}

Bioflocculant purification and concentration was done as described by Yokoi et al. [8] and Wu and Ye [32]. The fermentation broth was centrifuged (3000 rpm, $30 \mathrm{~min}, 15^{\circ} \mathrm{C}$ ) and cell pellets separated from the supernatant by decantation. Afterwards, the supernatant was mixed with ice cold ethanol (95\%), at volume to volume ratio of $1: 4$ to precipitate the bioflocculant and kept at $4{ }^{\circ} \mathrm{C}$ in a cold cabinet for $16 \mathrm{~h}$. The resulting precipitate was collected by centrifugation (10,000 rpm, $\left.30 \mathrm{~min}, 15^{\circ} \mathrm{C}\right)$ and re-dissolved in distilled water at ratio 1:4 (vol). This procedure was repeated twice and afterwards the partially purified bioflocculant (PPB) obtained was lyophilized. To another set, further purification, prior to lyophilization was carried out. The bioflocculant concentrate was dissolved in $0.05 \mathrm{M} \mathrm{NaCl}$ and $4 \mathrm{~mL}$ of $10 \%$ cetylpyridinium chloride (CPC) solution and the mixture stirred until the polysaccharide-CPC complex was completely solubilized. The mixture was left overnight at room temperature $\left(\sim 25^{\circ} \mathrm{C}\right)$ after which the precipitate was recovered by centrifugation $(10,000 \mathrm{rpm}, 30 \mathrm{~min}$, $\left.15{ }^{\circ} \mathrm{C}\right)$. This process was repeated in two successive stages. Thereafter, the bioflocculant was re-dissolved in distilled water and dialyzed overnight against distilled water at $4{ }^{\circ} \mathrm{C}$ and the dialyzed polymer was re-precipitated with ice cold ethanol, followed by vacuum drying and lyophilisation [33]. The lyophilized fractions were designated as CPB and used for further flocculation analysis and characterization studies.

\subsection{Effect of $\mathrm{pH}$ and Cations on Flocculation Activity}

The flocculation activity of the partial and CPC purified bioflocculant was assessed using kaolin clay suspension method as described in section 3.4 above. However, $0.4 \mathrm{mg} / \mathrm{mL}$ of the purified 
bioflocculant was used in place of the bioflocculant free broth. The effect of $\mathrm{pH}$ on flocculation activity was determined by varying the $\mathrm{pH}$ of the kaolin clay suspension from 2 to 11 . Likewise, the cation sources were varied from monovalent $(\mathrm{NaCl}$ and $\mathrm{KCl})$ to divalent $\left(\mathrm{CaSO}_{4} \cdot \mathrm{H}_{2} \mathrm{O} ; \mathrm{MgCl}_{2}\right.$; $\mathrm{MnCl} \cdot 4 \mathrm{H}_{2} \mathrm{O}$ and $\left.\mathrm{FeSO}_{4}\right)$ and trivalent $\left(\mathrm{FeCl}_{3}\right)$ metal ions, respectively. All other conditions for the flocculation assay remained the same.

\subsection{Compositional Analyses of Bioflocculants}

The total sugar and protein content of the purified bioflocculant were determined by the phenol-sulfuric acid method using glucose as the standard solution [34], and Folin-phenol method [35] using bovine serum albumen (BSA) as standard. Similarly, neutral sugar content was determined by the anthrone reaction [36] while amino sugars were determined in accordance with the methods of Elson-Morgan and Morgan-Elson, as seen in Chaplin and Kennedy [37] and lastly, uronic acids were determined using the carbazole-sulfuric acid method as described by Li et al. [26].

\subsection{SEM Imaging, Elemental Analysis and FTIR Spectroscopy of Purified Bioflocculant}

Bioflocculant samples placed on carbon coated stub were gold coated in a gold coating chamber, using Eiko IB.3 ION coater, thereafter; the scanning electron microscopic (SEM) image of the bioflocculant was obtained using JEOL JSM-6390LV FEI XL30 (JEOL; USA) scan electron microscope. The SEM was equipped with Noran Six 200 Energy Dispersive X-ray (EDX) Analyzer, and this was used to obtain the elemental composition of the bioflocculants. Similarly, the functional groups of these flocculants were analyzed using a Fourier transform infrared (FT-IR) spectrophotometer (2000 FTIRS Spectrometer; Perkin Elma System) over a wave number range of 4000 to $500 \mathrm{~cm}^{-1}$.

\subsection{Thermal Studies of Purified Bioflocculant}

Thermogravimetric analysis of the purified bioflocculants was carried out using a thermogravimetric analyzer (TGA 7; Perkin Elmer, Waltham, MA, USA) fitted with thermal analysis controller (TAC 7/DX). About 2-3 mg of partial and CPC purified bioflocculant, each was loaded into an alumina cup and weight changes recorded as a function of temperature for a $10{ }^{\circ} \mathrm{C} \mathrm{min}{ }^{-1}$ temperature gradient between $20{ }^{\circ} \mathrm{C}$ and $900{ }^{\circ} \mathrm{C}$. A purge gas of flowing nitrogen at a rate of $20 \mathrm{~mL} \mathrm{~min}{ }^{-1}$ was used. Likewise, melting point/decomposition temperature of the bioflocculant was determined using Gallenkamp melting point apparatus.

\subsection{Identification of the Test Actinobacteria}

The bioflocculant producing actinobacteria was identified via molecular technique as described by Cook and Mayers, [38]. The actinobacteria 16S rDNA gene was amplified by polymerase chain reaction (PCR) followed by sequence analysis of the amplified gene. The actinobacterial DNA was extracted through the boiling method and the PCR amplification was carried out in $50 \mu \mathrm{L}$ reaction volume containing $2 \mathrm{mM} \mathrm{MgCl}_{2}$, $2 \mathrm{U}$ Supertherm Taq polymerase, $150 \mathrm{mM}$ of each dNTP, $0.5 \mathrm{mM}$ of each primer (F1: 59-AGAGTTTGATCITGGCTCAG-39; I = inosine and primer R5: 59-ACGGITACCTTGTTACGAC TT-39) and $2 \mathrm{~mL}$ of the template DNA. Primer F1 and R5 binds to 
base positions 7-26 and 1496-1476 of the 16S rRNA gene of Streptomyces ambofaciens ATCC 23877, respectively [38]. The PCR condition included the following: initial denaturation $\left(96{ }^{\circ} \mathrm{C}\right.$ for 2 min), 30 cycles of denaturation $\left(96{ }^{\circ} \mathrm{C}\right.$ for $\left.45 \mathrm{~s}\right)$, annealing $\left(56{ }^{\circ} \mathrm{C}\right.$ for $30 \mathrm{~s}$ ) and extension $\left(72{ }^{\circ} \mathrm{C}\right.$ for $2 \mathrm{~min}$ ), and a final extension ( $72{ }^{\circ} \mathrm{C}$ for $5 \mathrm{~min}$ ). Gel electrophoresis of PCR products were conducted on $1 \%$ agarose gels to confirm that a fragment of the correct size had been amplified. Automated sequencing of the 16S rRNA genes of the bacterial isolates was performed using the Spectrumedix SCE2410 genetic analysis system with 24 capillaries. The sequencing reactions were performed according to the manufacturer's instructions, using the Big Dye version 3.1 dye terminator cycle sequencing kit (Applied Biosystems) and 27F primer. The sequences were edited manually based on the most similar sequences.

\section{Conclusions}

Streptomyces sp. Gansen produced proteoglycan bioflocculant composed of uronic acids, neutral sugars, amino sugars and proteins with functional groups such as hydroxyl, carboxyl and amino groups favorable for flocculation. Bioflocculant production was optimal at log phase and optimum conditions include $2 \%(\mathrm{v} / \mathrm{v})$ starter culture of $1.5 \times 10^{8} \mathrm{cfu} / \mathrm{mL}$, agitation speed of $160 \mathrm{rpm}, \mathrm{pH}$ of 6.8 , and incubation temperature of $30^{\circ} \mathrm{C}$. Glucose, ammonium sulfate and magnesium chloride served as the best carbon, nitrogen and cation source for bioflocculant production. These results suggest promising application of these bioflocculants as they effectively flocculated kaolin clay in aqueous media.

\section{Acknowledgments}

We are grateful to the University of Fort Hare for financial support.

\section{References}

1. Toyozo, H.; Yasumitsu, M. Reuse of carwash water with a cellulose acetate ultrafiltration membrane aided by flocculation and activated carbon treatments. Desalination 2004, 169, 257-267.

2. Deng, S.B.; Yu, G.; Ting, Y.P. Production of a bioflocculant by Aspergillus parasiticus and its application in dye removal. Colloids Surf. B Biointerfaces 2005, 44, 179-186.

3. Salipira, K.L.; Mamba, B.B.; Krause, R.W.; Malefetse, T.J.; Durbach, S.H. Cyclodextrin polyurethanes polymerised with carbon nanotubes for the removal of organic pollutants. Water SA 2008, 34, 113-118.

4. Liu, W.; Yuan, H.L.; Yang. J.S.; Li, B.Z. Characterization of bioflocculants from biologically aerated filter backwashed sludge and its application in dying wastewater treatment. Bioresour. Technol. 2009, 100, 2629-2632.

5. Jang, J.H.; Ike, M.; Kim, S.M.; Fujita, M. Production of a novel bioflocculant by fed-batch culture of Citrobacter sp. Biotechnol. Lett. 2001, 23, 593-597.

6. Salehizadeh, H.; Shojaosadati, S.A. Extracellular biopolymeric flocculants recent trends and biotechnological importance. Biotechnol. Adv. 2001, 19, 371-385. 
7. Haijun, W.; Qingbiao, L.; Rui, L.; Yuanpeng, W.; Xiaoling, Z.; Ning, H. Fed-batch production of a bioflocculant from Corynebacterium glutamicum. J. Ind. Microbiol. Biotechnol. 2010, 37, 1203-1209.

8. Yokoi, H.; Natsuda, O.; Sachio, J.H.; Takasaki, Y. characteristics of a biopolymer flocculant produced by Bacillus sp. PY-90. J. Ferment. Bioeng. 1995, 79, 378-380.

9. Dearfield, K.L.; Albernathy, C.O.; Ottley, M.S.; Brantner, J.H.; Hayes, P.F. Acrylamide: Its metabolism, developmental and reproductive effects, genotoxicity, and carcinogenicity. Mutat. Res. 1988, 195, 45-77.

10. Smith, M.A.; Perry, G.; Sayre, L.M.; Anderson, V.E.; Beal, M.F.; Kowall, N. Oxidative damage in Alzheimer's. Nature 1996, 382, 120-121.

11. Stephens, C. Microbiology: Breaking down biofilms. Curr. Biol. 2002, 12, 132-134.

12. Rudén, C. Acrylamide and cancer risk-expert risk assessments and the public debate. Food Chem. Toxicol. 2004, 42, 335-349.

13. He, N.; Li, Y.; Chen, J. Production of a novel polygalacturonic acid bioflocculant REA-11 by Corynebacterium glutamicum. Bioresour. Technol. 2004, 94, 99-105.

14. Cosa, S.; Mabinya, L.V.; Olaniran, O.A.; Okoh, O.O.; Bernard, K.; Deyzel, S.; Okoh, A.I. Bioflocculant production by Virgibacillus sp. Rob isolated from the bottom sediment of Algoa Bay in the eastern cape, South Africa. Molecule 2011, 16, 2431-2442.

15. Mullins, J.T.; NeSmith, C. Integrated ethanol production and utilization system for small farms. Biomass 1984, 6, 155-166.

16. Gibbons, W.R.; Westby, C.A. Effects of inoculum size on solid-phase fermentation of fodder beets for fuel ethanol production. Appl. Environ. Microb. 1986, 52, 960-962.

17. Mabinya, V.L.; Cosa, S.; Nwodo, U.U.; Okoh, A.I. Studies on bioflocculant production by Arthrobacter sp. Raats, a freshwater bacteria isolated from Tyume River, South Africa. Int. J. Mol. Sci. 2012, 13, 1054-1065.

18. Gonzalez, J.F.; Hu, W.S. Effect of glutamate on the degradation of pentachlorophenol by Flavobacterium sp. Appl. Microbiol. Biotechnol. 1991, 36, 100-104.

19. Takagi, H.; Kadowaki, K. Poly galactosamine produced by a microorganism. Chitin Nat. Technol. 1985, 3, 121-128.

20. Lu, W.; Zhang, T.; Zhang, D.; Li, C.; Wen, J.; Du, L. A novel bioflocculant produced by Enterobacter aerogenes and its use in defecating the trona suspension. Biochem. Eng. J. 2005, 27, 1-7.

21. Gong, W.; Wang, S.; Sun, F.; Liu, X.W.; Yue, Q.Y.; Gao, B.Y. Bioflocculant production by culture of Serratia ficaria and its application in wastewater treatment. Bioresour. Technol. 2008, 99, 4668-4674.

22. Piyo, N.; Cosa, S.; Mabinya, L.V.; Okoh, A.I. Assessment of bioflocculant production by Bacillus sp. Gilbert, a marine bacterium isolated from the bottom sediment of Algoa Bay. Mar. Drugs 2011, 9, 1232-1242.

23. Li, W.W.; Zhou, W.Z.; Zhang, Y.Z.; Wang, J.; Zhu, X.B. Flocculation behaviour and mechanism of an exopolysaccharide from the deepsea psychrophilic bacterium Pseudoalteromonas sp. SM9913. Bioresour. Technol. 2008, 99, 6893-6899. 
24. Wang, L.; Ma, F.; Qu, Y.; Sun, D.; Li, A.; Guo, J.; Yu, B. Characterization of a compound bioflocculant produced by mixed culture of Rhizobium radiobacter F2 and Bacillus sphaeicus F6. World J. Microbiol. Biotechnol. 2011, 27, 2559-2565.

25. He, N.; Li, Y.; Chen, J.; Lun, S.Y. Identification of a novel bioflocculant from a newly isolated Corynebacterium glutamicum. Biochem. Eng. J. 2002, 11, 137-148.

26. Li, J.; Kisara, K.; Danielsson, S.; Lindstrom, M.E.; Gellerstedt, G. An improved methodology for the quantification of Uronic Acid Units in Xylans and other polysaccharides. Carbohydr. Res. 2007, 342, 1442-1449.

27. Schmitt, J.; Flemming, H. FTIR-spectroscopy in microbial and material analysis. Int. Biodeterior. Biodegrad. 1998, 41, 1-11.

28. Coates, J. Interpretation of Infrared Spectra, a Practical Approach. In Encyclopedia of Analytical Chemistry; Meyers, R.A., Ed.; John Wiley \& Sons Ltd: Chichester, UK, 2000.

29. Niu, S.; Han, K.; Zhou, F.; Lu, C. Thermogravimetric analysis of the decomposition characteristics of two kinds of calcium based organic compounds. Powder Technol. 2011, 209, 46-52.

30. Zhang, Z.Q.; Lin, B.; Xia, S.Q.; Wang, X.J.; Yang, A.M. Production and application of a bioflocculant by multiple-microorganism consortia using brewery wastewater as carbon source. J. Environ. Sci. 2007, 19, 660-666.

31. National Committee for Clinical Laboratory Standards. Methods for Dilution in Antimicrobial Susceptibility Tests: Approved Standard M2-A5; National Committee for Clinical Laboratory Standards: Vilanova, PA, USA, 1993.

32. Wu, J.Y.; Ye, H.F. Characterization and flocculating properties of an extracellular biopolymer produced from a Bacillus subtilis DYU1 isolate. Proc. Biochem. 2007, 42, 1114-1123.

33. Kumar, C.G.; Joo, H.S.; Choi, J.W.; Koo, Y.M.; Chang, C.S. Purification and characterization of an extracellular polysaccharide from haloalkalophilic Bacillus sp. I-450. Enzym. Microbial. Technol. 2004, 34, 673-681.

34. Dubois, M.; Gilles, K.A.; Hamilton, J.K.; Rebers, P.A.; Smith, F. Colorimetric method for determination of sugars and related substances. Anal. Chem. 1956, 28, 350-356.

35. Lowry, O.H.; Rosebrough, N.J.; Farr, A.L.; Randall, R.J. Protein measurement with the folin-phenol reagents. J. Biol. Chem. 1951, 193, 265-275.

36. Zhang, W. Biological-Chemical Analysis of Glycoconjugates, 2nd ed.; Zhejiang University Press: Hangzhou, China, 2003.

37. Chaplin, M.F.; Kennedy, J.F. Carbohydrate Analysis, 2nd ed.; Oxford University Press: New York, NY, USA, 1994.

38. Cook, A.E.; Meyers, P.R. Rapid identification of filamentous actinomycetes to the genus level using genus-specific 16S rRNA gene restriction fragment patterns. Int. J. Syst. Evol. Microbiol. 2003, 53, 1907-1915.

(C) 2012 by the authors; licensee MDPI, Basel, Switzerland. This article is an open access article distributed under the terms and conditions of the Creative Commons Attribution license (http://creativecommons.org/licenses/by/3.0/). 